\title{
Genetic Behavior of Some Agronomic Characters in Three Bread Wheat Crosses under Different Environmental Conditions
}

\author{
E. L. Elmassry ${ }^{1}$ and Marwa, M. El-Nahas ${ }^{2}$ \\ ${ }^{1}$ Wheat Research Department, Field Crops Research Institute, A.R.C. \\ ${ }^{2}$ Crop Science Department, Faculty of Agriculture, Minufiya University \\ Corresponding author. E-mail: elmassry1010@yahoo.com
}

\begin{abstract}
This investigation was carried out at the Experimental Farm of Gemmeiza Agriculture Research Station, Egypt during the three successive seasons,i.e., 2015/2016,2016/2017 and 2017/2018 to study nature of gene action for yield and its components, heterosis expression, heritability and expected genetic advance under normal and water stress conditions. Six populations model (P1, P2, F1, F2, BC1 and BC2) was used in this study for three crosses; (I) Gemmeiza 11× Giza 168, (II) Giza 171 $\times$ Shandawel 1 and (III) Gemmeiza 9× Misr1. Means of the six generations were recorded for eight characters, i.e. number of spikes per plant, plant height, main spike length, number of spikelets per main spike, number of kernels per main spike, main spike yield, grain yield per plant and 1000- kernels weight. Results revealed that the coincidence of sign and magnitude of heterosis and inbreeding depression was also detected for most characters in the three crosses under both conditions. Study of generation means analysis revealed that additive, dominance and epistasic effects were involved in the inheritance of yield and its components. Additive (a) and dominance (d) genes effects were significant for most studied characters under both conditions. High heritability estimates in broad sense were detected for all studied characters in the three crosses under both conditions, except, main spike yield in the first cross under stress. Narrow sense heritability estimates were found to be high for most characters under both conditions. Moderate to high genetic advance $(\Delta \mathrm{g} \%)$ was detected for all characters of the three crosses under the two environments, except, plant height for the three crosses under normal condition and first and second cross under stress condition. The highest estimates of narrow sense heritability associated with highest genetic advance for most of the studied characters in most of crosses under both conditions indicated sufficient improvement of the variable characters. These results indicated the possibility of practicing selection in early generations for these characters.
\end{abstract}

Key words: Wheat, Gene action, Heritability and Six parameter models.

\section{INTRODUCTION}

Wheat is the most important cereal crop in Egypt and worldwide. In Egypt, increasing grain yield of cereal crops is consider one of the important national goals to face the growing needs of the population, therefore, it has become necessary to develop genotypes which consistently show superior performance. The development of well adapted cultivars to a wide range of environmental stresses is the ultimate goal of plant breeders in wheat. Among the environmental stresses drought is the second contributor to yield reduction after disease losses (Farshadfar et al., 2001 and Farshadfar et al., 2008). Improving drought resistance is, therefore a major objective in plant breeding programs for rainfed agriculture (Ehdaie and Waines, 1993). The main objective of the wheat program is boost average national wheat grain yield. In this context, knowledge of the nature of gene action involved in the control of quantitative characters is important to identify the best parents and crosses and to make decisions about the appropriate selection strategies to manage progenies. In the present investigation, generation mean analysis was used for estimating gene effects and non-allelic gene action. Such analysis is very useful for the rapidly obtaining the overall information on various genetic system involved in segregating generations which may lead fixing favorable gene action for speedy gains. Plant breeders and geneticists frequently use generation mean analysis to obtain information of gene action controlling the economic characters in wheat (Akhtar and Chowdhry, 2006; Khaled, 2007 and Farag, 2009).

The aim of this investigation was to study the heterosis, inbreeding depression, gene action, heritability, as well as predicted genetic advance in three wheat crosses using six population under two different environmental conditions.These information would be used in the approval of efficient breeding strategies in wheat breeding.

\section{MATERIALS AND METHODS}

The present study was carried out at the Experimental Farm of El-Gemmeiza Agricultural Research Station, ARC, Egypt during the three successive seasonsof 2015/2016, 2016/2017 and 2017/2018.

The genetic materials used in this investigation included six bread wheat cultivars(Triticum aestivum L.) representing a wide range of diversity for several agronomic characters. The code number, 
names and pedigree of these parental genotypes are presented in Table (1).

In 2015/2016 season, three crosses were made among the parents to produce $F_{1}$ hybrid seeds for crosses, i.e; (I) Gemmeiza 11× Giza 168, (II) Giza 171× Shandawel 1 and (III) Gemmeiza 9× Misr 1 . In 2016/2017 season, F1 plants were selfed to produce $\mathrm{F} 2$ seeds and backcrossed to the parents to produce BC1 and BC2 seeds. In 2017/2018 season, the six populations of the three crosses were grown in two separate experiments in a randomized complete block design with three replicates for each one under normal and water stress conditions. The first experiment under normal condition $(\mathrm{N})$ was irrigated three times after planting irrigation, i.e. four irrigations were given through the whole season. The second experiment was under water stress (S) where it was given only one surfaceirrigation 50 days after planting irrigation, i.e. two irrigations through the whole growing season. Each block comprised five rows of $\mathrm{F} 2$, two rows of $\mathrm{Bc} 1$ and $\mathrm{Bc} 2$ and one row of other three nonsegregated populations. The experimental units consisted of single rows three meters long with $30 \mathrm{~cm}$. between rows, plants within rows were $10 \mathrm{~cm}$. apart allowing a total of 30 plants per row. Each experiment was surrounded by a wide border $(20 \mathrm{~m})$ to minimize the underground water permeability. All other cultural practices, except irrigation, were applied as recommended for wheat cultivation in the area.

Data were recorded on individual guarded plants: (20 plants for unsegregated generations ( $\mathrm{P} 1$, $\mathrm{P} 2$ and F1), 90 plants in $\mathrm{BC} 1$ and $\mathrm{BC} 2$ and 200 plants in F2 for the studied characters as follows: number of spikes per plant, plant height $(\mathrm{cm})$, main spike length $(\mathrm{cm})$, no. of spikelets per main spike, no. of kernels per main spike, main spike yield, grain yield per plant (gm.) and 1000. Kernel weight Statistical analysis:

The t-test was used to examine the existence of genetic variance between parental means. Statistical procedures used herein would only be computed if the $F_{2}$ genetic variance found to be significant. A one tail $(\mathrm{F})$ ratio was used to examine the existence of genetic variance within the $F_{2}$ population. Heterosis $(\mathrm{H})$ was expressed as percent increase of the $\mathrm{F}_{1}$ mean performance above the respective better parent (Fonseca and Patterson, 1968). Inbreeding depression (I.d) was measured as the average percent decrease of the $F_{2}$ from the $F_{1}$ values. Nature of gene action was studied according to the relationships illustrated by Gamble, 1962. In this procedure the means of the six populations of each cross were used to estimate the six parameters of gene action ( $\mathrm{m}, \mathrm{a}, \mathrm{d}$, aa, ad and $\mathrm{dd})$. A test of significance of these parameters was conducted by the t-test. Heritability was estimated in both broad and narrow senses for $\mathrm{F}_{2}$ generation according to Mather's procedure, 1949. The predicted genetic advance under selection $(\Delta \mathrm{G})$ was computed according to Johnson et al., 1955. This genetic gain represented as percentage of the $F_{2}$ mean performance was also obtained according to Miller et al., 1958.

\section{RESULTS AND DISCUSSIONS}

The validity of the varietal differences and the genetic variance within F2 populations of the three crosses i.e. (I) Gemmeiza 11× Giza 168, Giza $171 \times$ Shandawel 1 and Gemmeiza $9 \times$ Misr 1 under normal $(\mathrm{N})$ and stress (S) conditions for studied characters are presented in Table (2).

Varietal differences in response to their genetic background were found to be significant in most studied characters in the three crosses under this investigation. The genetic variances within $\mathrm{F}_{2}$ populations were also found to be significant for all studied characters in the three crosses under both conditions. Consequently, the various genetical parameters used in this investigation were computed for all studiedcharacters.

Table 1: Name andpedigree of the six parental bread wheat varieties.

\begin{tabular}{lll}
\hline & \multicolumn{1}{c}{ Name } & \multicolumn{1}{c}{ Pedigree and selection history } \\
\hline \multirow{3}{*}{ Cross 1 } & Gemmeiza 11 & BOW"S"/KVZ"S"//7C/SERI82/3/GIZA168/SAKHA61 \\
& ( P1) & CGM7892-2GM-1GM-2GM-0GM \\
\cline { 2 - 3 } & Giza 168 & MRL/ BUC// SERI \\
& (P2) & CM 93046-8M-0Y-0M-2Y-0B-0GZ \\
\hline \multirow{3}{*}{ Cross 2 } & Giza 171 & Sakha 93/ Gemmeiza 9 \\
& ( P1) & Gz 2003-101-1Gz- 4Gz-1Gz-2Gz-0Gz \\
\cline { 2 - 3 } & Shandawel 1 & SITE/MO/4/NAC/TH.AC//3*PVN/3/MIRLO/BUC. \\
& (P2) & CMSS93B00S 67S-72Y-010M-010Y-010M-3y-OM-0THY-0SH \\
\hline \multirow{3}{*}{ Cross 3 } & Gemmeiza 9 & ALD "S" /HUAC // CMH 74 A. 630/SX \\
& ( P1) & CGM 4583 - 5 GM - 1GM - 0GM \\
\cline { 2 - 3 } & Misr 1 & OASIS/SKAUZ//4*BCN/3/2*PASTOR. \\
& (P2) & CMSS00Y01881T -050M-030Y-030M-030WGY-33M-0Y--0EGY \\
\hline
\end{tabular}


Table 2: T-test and F-test for all studied charactersi $n$ the three bread wheat crosses (I) Gemmeiza 11× Giza 168, (II) Giza 171 $\times$ Shandawel 1 and (III) Gemmeiza 9× Misr 1 under normal (N) and stress (S) conditions in 2017/2018.

\begin{tabular}{|c|c|c|c|c|}
\hline Characters & Condition & Cross & T-test & F-test \\
\hline \multirow{6}{*}{ No. of spikes per plant } & \multirow{3}{*}{$\mathrm{N}$} & $\mathrm{C} 1$ & $*$ & $* *$ \\
\hline & & $\mathrm{C} 2$ & $* *$ & $* *$ \\
\hline & & $\mathrm{C} 3$ & $* *$ & $* *$ \\
\hline & \multirow{3}{*}{$\mathrm{S}$} & $\mathrm{C} 1$ & $* *$ & $* *$ \\
\hline & & $\mathrm{C} 2$ & N.S. & $* *$ \\
\hline & & $\mathrm{C} 3$ & N.S. & $* *$ \\
\hline \multirow{6}{*}{ Plant height (cm) } & \multirow{3}{*}{$\mathrm{N}$} & $\mathrm{C} 1$ & $* *$ & $* *$ \\
\hline & & $\mathrm{C} 2$ & N.S. & $* *$ \\
\hline & & $\mathrm{C} 3$ & $* *$ & $* *$ \\
\hline & \multirow{3}{*}{$\mathrm{S}$} & $\mathrm{C} 1$ & $* *$ & $* *$ \\
\hline & & $\mathrm{C} 2$ & $* *$ & $* *$ \\
\hline & & $\mathrm{C} 3$ & N.S. & $* *$ \\
\hline \multirow{6}{*}{ Main spike length(cm) } & \multirow{3}{*}{$\mathrm{N}$} & $\mathrm{C} 1$ & $*$ & $* *$ \\
\hline & & $\mathrm{C} 2$ & $* *$ & $* *$ \\
\hline & & $\mathrm{C} 3$ & $*$ & $* *$ \\
\hline & \multirow{3}{*}{$\mathrm{S}$} & $\mathrm{C} 1$ & $* *$ & $* *$ \\
\hline & & $\mathrm{C} 2$ & $* *$ & $* *$ \\
\hline & & $\mathrm{C} 3$ & N.S. & $* *$ \\
\hline \multirow{6}{*}{ No .of spikelets per main spike } & \multirow{3}{*}{$\mathrm{N}$} & $\mathrm{C} 1$ & $* *$ & $* *$ \\
\hline & & $\mathrm{C} 2$ & $* *$ & $* *$ \\
\hline & & $\mathrm{C} 3$ & $* *$ & $* *$ \\
\hline & \multirow{3}{*}{$\mathrm{S}$} & $\mathrm{C} 1$ & $* *$ & $* *$ \\
\hline & & $\mathrm{C} 2$ & $* *$ & $* *$ \\
\hline & & $\mathrm{C} 3$ & N.S. & $* *$ \\
\hline \multirow{6}{*}{ No. of kernels per main spike } & \multirow{3}{*}{$\mathrm{N}$} & $\mathrm{C} 1$ & $* *$ & $* *$ \\
\hline & & $\mathrm{C} 2$ & $* *$ & $* *$ \\
\hline & & $\mathrm{C} 3$ & N.S. & ** \\
\hline & \multirow{3}{*}{$\mathrm{S}$} & $\mathrm{C} 1$ & $* *$ & $* *$ \\
\hline & & $\mathrm{C} 2$ & $* *$ & $* *$ \\
\hline & & $\mathrm{C} 3$ & $* *$ & $* *$ \\
\hline \multirow{6}{*}{ Main spike yield(g) } & \multirow{3}{*}{$\mathrm{N}$} & $\mathrm{C} 1$ & N.S. & * \\
\hline & & $\mathrm{C} 2$ & N.S. & $* *$ \\
\hline & & $\mathrm{C} 3$ & N.S. & $* *$ \\
\hline & \multirow{3}{*}{$\mathrm{S}$} & $\mathrm{C} 1$ & N.S. & $*$ \\
\hline & & $\mathrm{C} 2$ & $* *$ & $* *$ \\
\hline & & $\mathrm{C} 3$ & N.S. & * \\
\hline \multirow{6}{*}{ Grain yield per plant(g) } & \multirow{3}{*}{$\mathrm{N}$} & $\mathrm{C} 1$ & $* *$ & $* *$ \\
\hline & & $\mathrm{C} 2$ & N.S. & $*$ \\
\hline & & $\mathrm{C} 3$ & N.S. & $* *$ \\
\hline & \multirow{3}{*}{$\mathrm{S}$} & $\mathrm{C} 1$ & $* *$ & $* *$ \\
\hline & & $\mathrm{C} 2$ & * & $* *$ \\
\hline & & $\mathrm{C} 3$ & N.S. & $* *$ \\
\hline \multirow{6}{*}{ 1000. Kernel weight (g) } & & $\mathrm{C} 1$ & $* *$ & $* *$ \\
\hline & $\mathrm{N}$ & $\mathrm{C} 2$ & N.S. & $* *$ \\
\hline & & $\mathrm{C} 3$ & N.S. & $* *$ \\
\hline & & $\mathrm{C} 1$ & $* *$ & $* *$ \\
\hline & $\mathrm{S}$ & $\mathrm{C} 2$ & N.S. & $* *$ \\
\hline & & $\mathrm{C} 3$ & $*$ & $*$ \\
\hline
\end{tabular}

*,** Significant at 0.05 and 0.01 probability levels, respectively. N.S. insignificant at 0.05 probability level. 
The existence of the significant genetic variability in $F_{2}$ populations in spite of the insignificant differences between the parental wheat cultivars may suggest that the genes of like effects were not completely associated in the parental cultivars i.e. these genes are dispersed (Mather and Jinks, 1982).

Means and variance of the six populations $\mathrm{P} 1$, $\mathrm{P} 2, \mathrm{~F} 1, \mathrm{~F} 2, \mathrm{BC} 1$ and $\mathrm{BC} 2$ for all studied characters in the three crosses under the two environmental conditions are shown in Table (3). Differences between genotypes were significant in most characters under study. The $\mathrm{F}_{2}$ genetic variance was also significant for all characters in the three crosses under the two different environmental, revealing genetic diversity for these attributes in the materials, thus validating the genetic analysis of the characters following the technique of Mather and Jinks (1982).

The mean values of the studied characters under the two environments, $F_{1}$ generation values were higher than the two parents except mean spike length under stress and 1000-kernel weight under the two treatments of irrigation indicating the presence of partial-dominance. Concerning $\mathrm{F}_{2}$ mean, the values were less than the $F_{1}$ mean values for all studied characters under the two conditions revealing the importance of non-additive components of genetic variance in this study. Generally, the six population mean values were higher increased in the normal condition than in the stress condition for all studied characters, revealing the importance of water for plant behavior.

It is worthily to note that the water stress had affected all studied characters. Many researchers introduced some reasons for these reductions. ElHawary (2006) reported that number of spikes/plant and grain yield/plant had significantly decreased by water stress.In this regard, Elmassry et al. (2016) reported that water stress treatment decreased the mean of all genotypes for plant height, yield and yield components.

\section{Heterosis and inbreeding depression:}

Heterosis is expressed as the percentage deviation of F1 mean performance from the better parent of the characters. In this concern, percentage of heterosis over better parent values is presented in Table (4).

Significant positive heterosis relative to better parent was obtained for most characters studied in the three crosses under both conditions. While, the first cross was produced negative significant to better parent for main spike length (-9.89)under stress condition and 1000- kernel weight under both condition.

Similar results were already reported by Zaazaa et al. (2012) for spike length, number of spikes/plant, number of spikelets /spike, grain weight/spike, number of grains/ spike, 1000-grain weight and grain yield/plant, Abd El-Rahman
(2013) for plant height, number of spikes per plant, kernel weight and grain yield per plant and Munesh et al. (2018) for grains per spike, grain weight per spike and 1000 grain

Significant heterobeltiosis in wheat is attributed to the major combined effects of additive $\mathrm{x}$ dominance and dominance $\times$ dominance gene effects. Absence of significant heterosis in other cases could be due to the internal cancellation of heterosis components. The results of heterosis suggested that hybrid vigour is available for the commercial production of wheat and selection of desirable hybrids among the crosses having heterotic and heterobeltiotic effects in other characters is the best way to improve the grain yield of bread wheat Memon (2010).

Inbreeding depression measures the reduction in performance of the F2 generation due to inbreeding. The results revealed that significant positive inbreeding depression for most studied characters in the three crosses under both conditions (Table 4). On the other hand, significant negative inbreeding depression values were detected for no .of spikelets per main spike and 1000-Kernel weight in the first cross $(-10.33,-11.08)$, respectively under normal irrigation. Khattab et al. (2010) reported that significant positive Inbreeding depression for grain weight/spike and no. of grains / spike.

The coincidence of sign and magnitude of heterosis and inbreeding depression was detected for most characters in the three crosses. This is logic and expected since the expression of heterosis in $F_{1}$ will be followed by a considerable reduction in $\mathrm{F}_{2}$ due to homozygosis.

\section{Gene effects:}

The estimates of the six parameters, i.e. means (m), additive (a), dominance (d), additive $\times$ additive (aa), additive $\times$ dominance $(\mathrm{ad})$ and dominance $\times$ dominance(dd) are presented in Table 5. Highly significance for the estimated values of mean effects (m) indicated that all the studied characters were quantitatively inheritance.

The additive gene effects (a)were significant and either positive or negative for all studied characters except no. of spikes per plant in the first cross under both condition and third cross only under normal condition, for plant height in third cross under both conditions, for main spike yield in third cross under stress condition, grain yield per plant in second cross under both condition and third cross under stress condition and first cross only under stress condition and 1000-kernel weight in second and third cross under normal case. The results obtained suggesting the potential for obtaining further improvement of these characters by practicing in selection their progenies. The results for all studied characters are in accordance with the previous findings of Abd El-Rahman (2013). 


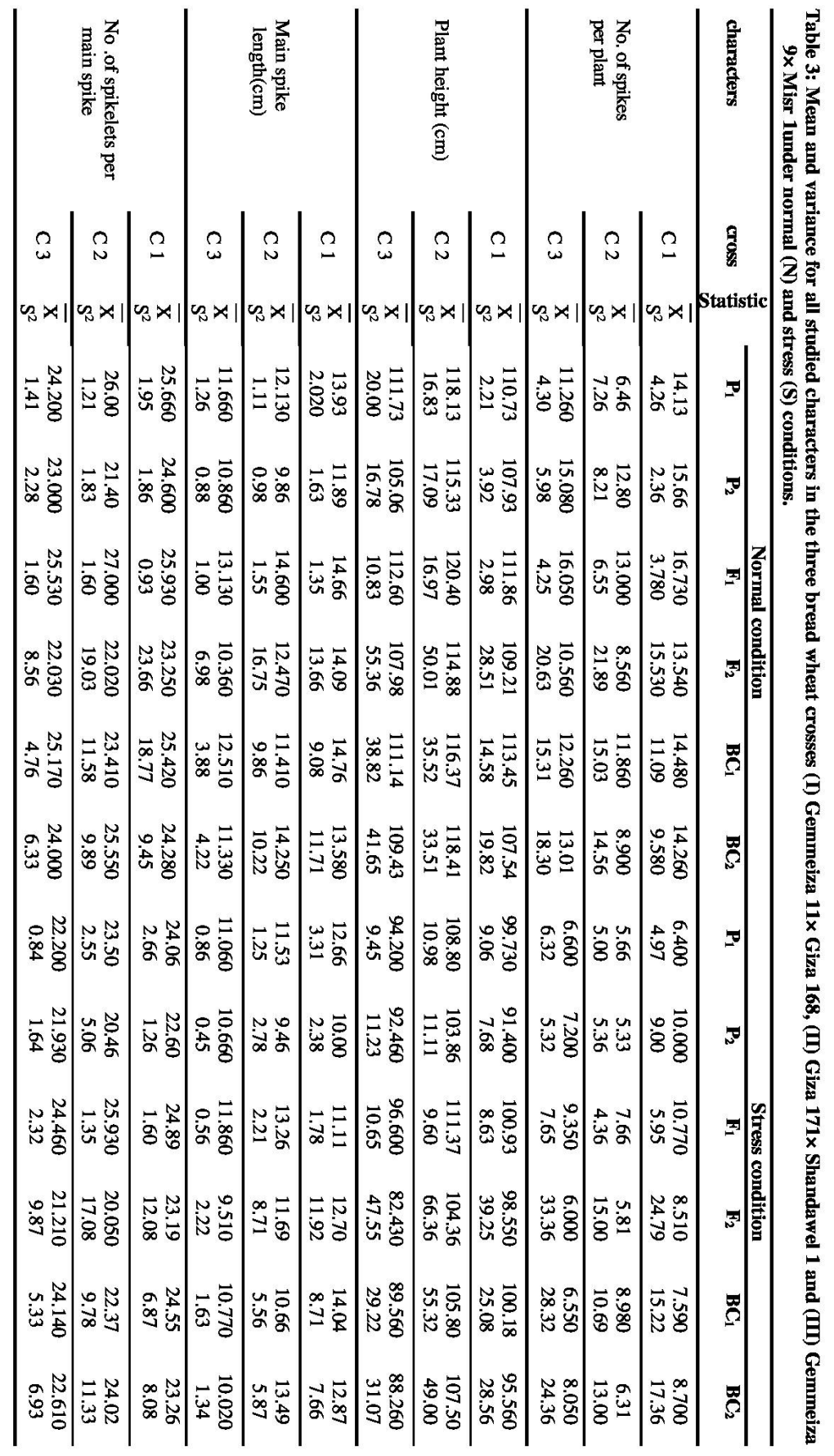




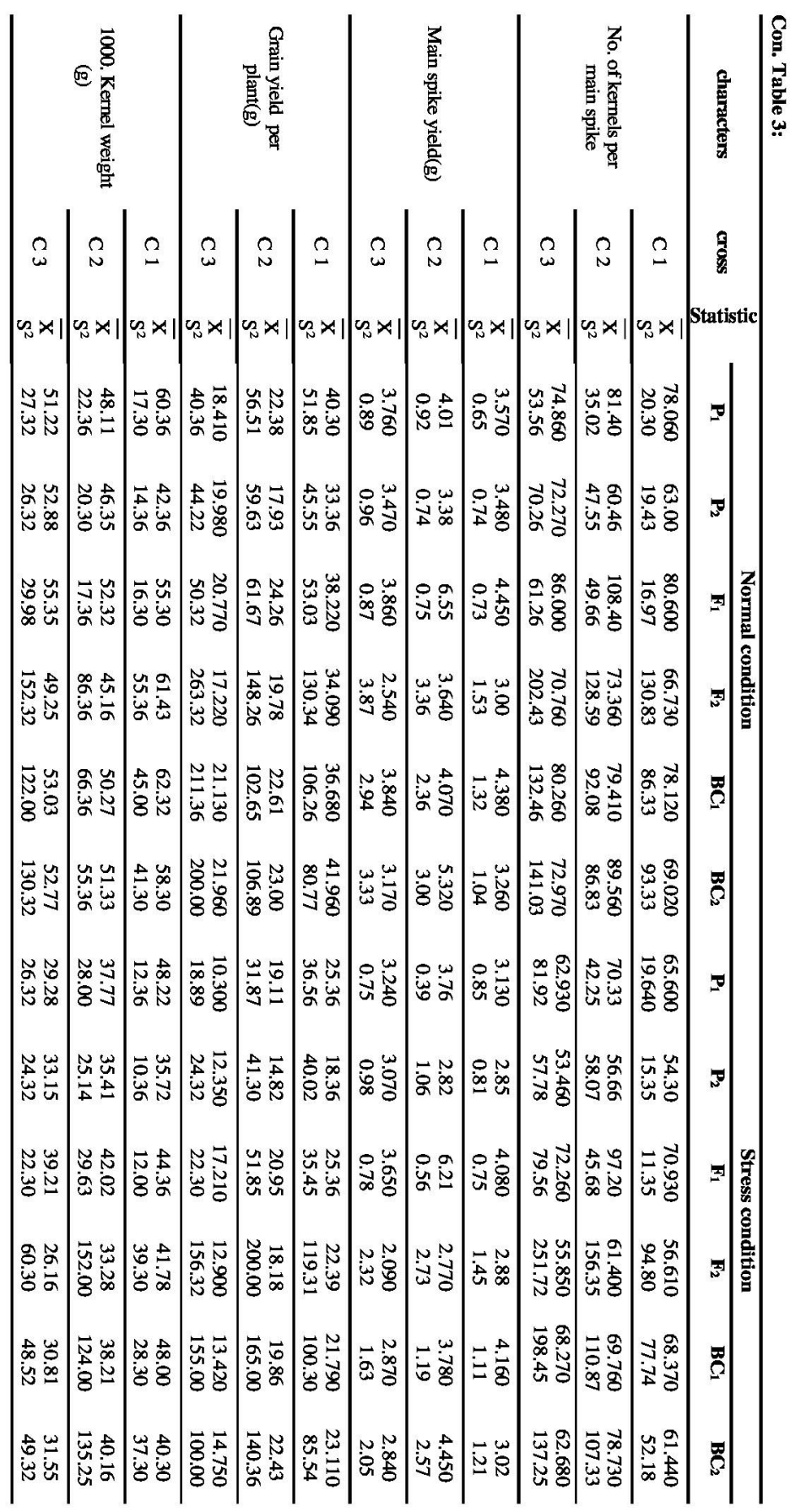


Table 4: Heterosis(\%) and inbreeding depression (\%) in the three bread wheat crosses (I) Gemmeiza 11× Giza 168, (II) Giza 171× Shandawel 1 and (III) Gemmeiza 9× Misr 1 under normal (N) and stress (S) conditions.

\begin{tabular}{|c|c|c|c|c|}
\hline Characters & Condition & Cross & $\begin{array}{c}\text { Heterosis \% } \\
\text { BP }\end{array}$ & $\begin{array}{c}\text { Inbreeding depression } \\
\%\end{array}$ \\
\hline \multirow{6}{*}{ No. of spikes per plant } & \multirow{3}{*}{$\mathrm{N}$} & $\mathrm{C} 1$ & 6.833 & $19.06^{* *}$ \\
\hline & & $\mathrm{C} 2$ & 0.93 & $34.15 * *$ \\
\hline & & $\mathrm{C} 3$ & 6.43 & $34.20 * *$ \\
\hline & \multirow{3}{*}{$\mathrm{S}$} & $\mathrm{C} 1$ & 7.700 & $20.98 * *$ \\
\hline & & $\mathrm{C} 2$ & 4.502 & $24.15 * *$ \\
\hline & & $\mathrm{C} 3$ & $29.86^{*}$ & $35.82 * *$ \\
\hline \multirow{6}{*}{ Plant height $(\mathrm{cm})$} & \multirow{3}{*}{$\mathrm{N}$} & $\mathrm{C} 1$ & $3.64 * *$ & $2.36^{*}$ \\
\hline & & $\mathrm{C} 2$ & $4.39 *$ & $4.58 *$ \\
\hline & & $\mathrm{C} 3$ & $7.17 * *$ & $4.10^{*}$ \\
\hline & \multirow{3}{*}{$\mathrm{S}$} & $\mathrm{C} 1$ & $10.42 * *$ & $2.35 *$ \\
\hline & & $\mathrm{C} 2$ & $7.23 * *$ & $6.29 * *$ \\
\hline & & $\mathrm{C} 3$ & $4.478^{*}$ & $14.66^{* *}$ \\
\hline \multirow{6}{*}{ Main spike length $(\mathrm{cm})$} & \multirow{3}{*}{$\mathrm{N}$} & $\mathrm{C} 1$ & 5.24 & 3.88 \\
\hline & & $\mathrm{C} 2$ & $20.36^{* *}$ & $14.58 *$ \\
\hline & & $\mathrm{C} 3$ & $12.60 *$ & $21.09 * *$ \\
\hline & \multirow{3}{*}{$\mathrm{S}$} & $\mathrm{C} 1$ & $-9.89 *$ & $14.31 * *$ \\
\hline & & $\mathrm{C} 2$ & $15.00 * *$ & $11.84 * *$ \\
\hline & & $\mathrm{C} 3$ & $7.23 *$ & $19.81 * *$ \\
\hline \multirow{6}{*}{ No .of spikelets per main spike } & \multirow{3}{*}{$\mathrm{N}$} & $\mathrm{C} 1$ & 1.052 & $-10.33 * *$ \\
\hline & & $\mathrm{C} 2$ & $3.84^{*}$ & $18.44 * *$ \\
\hline & & $\mathrm{C} 3$ & $5.49 *$ & $13.70 * *$ \\
\hline & \multirow{3}{*}{$\mathrm{S}$} & $\mathrm{C} 1$ & 2.953 & $6.24^{* *}$ \\
\hline & & $\mathrm{C} 2$ & $10.34 * *$ & $22.67 * *$ \\
\hline & & $\mathrm{C} 3$ & $10.18^{*}$ & $13.28 * *$ \\
\hline \multirow{6}{*}{ No. of kernels per main spike } & \multirow{3}{*}{$\mathrm{N}$} & $\mathrm{C} 1$ & 3.25 & $17.20 * *$ \\
\hline & & $\mathrm{C} 2$ & $33.17 * *$ & $32.32 * *$ \\
\hline & & $\mathrm{C} 3$ & $14.88 *$ & $17.72 * *$ \\
\hline & \multirow{3}{*}{$\mathrm{S}$} & $\mathrm{C} 1$ & $8.12 * *$ & $20.28 * *$ \\
\hline & & $\mathrm{C} 2$ & $38.20 * *$ & $36.83 * *$ \\
\hline & & $\mathrm{C} 3$ & $14.82 *$ & $22.71 * *$ \\
\hline \multirow{6}{*}{ Main spike yield(g) } & \multirow{3}{*}{$\mathrm{N}$} & $\mathrm{C} 1$ & $24.65^{*}$ & $32.58 * *$ \\
\hline & & $\mathrm{C} 2$ & $63.34 * *$ & $44.42 * *$ \\
\hline & & $\mathrm{C} 3$ & 2.66 & $34.19 * *$ \\
\hline & \multirow{3}{*}{$\mathrm{S}$} & $\mathrm{C} 1$ & $30.35 * *$ & 29.41 \\
\hline & & $\mathrm{C} 2$ & $65.16^{* *}$ & $55.39 * *$ \\
\hline & & $\mathrm{C} 3$ & 12.77 & $42.80 * *$ \\
\hline \multirow{6}{*}{ Grain yield per plant(g) } & \multirow{3}{*}{$\mathrm{N}$} & $\mathrm{C} 1$ & -4.96 & 10.99 \\
\hline & & $\mathrm{C} 2$ & 8.40 & 18.46 \\
\hline & & $\mathrm{C} 3$ & 3.95 & 17.09 \\
\hline & \multirow{3}{*}{ S } & $\mathrm{C} 1$ & 0.15 & 11.71 \\
\hline & & $\mathrm{C} 2$ & 9.62 & 13.22 \\
\hline & & $\mathrm{C} 3$ & $39.35^{*}$ & $25.04^{*}$ \\
\hline \multirow{6}{*}{ 1000. Kernel weight (g) } & & $\mathrm{C} 1$ & $-8.38 * *$ & $-11.08 * *$ \\
\hline & $\mathrm{N}$ & $\mathrm{C} 2$ & $8.75^{*}$ & $13.68 * *$ \\
\hline & & $\mathrm{C} 3$ & 4.67 & $11.02 * *$ \\
\hline & & $\mathrm{C} 1$ & $-8.01 * *$ & $5.81^{*}$ \\
\hline & $\mathrm{S}$ & $\mathrm{C} 2$ & $119.88 * *$ & $20.80 * *$ \\
\hline & & C3 & $18.28 * *$ & $33.28 * *$ \\
\hline
\end{tabular}

*,** Significant at 0.05 and 0.01 probability levels, respectively. 
Table 5: Gene action parameters in the three bread wheat crosses (I) Gemmeiza 11× Giza 168, (II) Giza 171× Shandawel 1 and (III) Gemmeiza 9× Misr 1 under normal (N) and stress (S) conditions.

\begin{tabular}{|c|c|c|c|c|c|c|c|c|}
\hline \multirow[b]{2}{*}{ Characters } & \multirow[b]{2}{*}{ Condition } & \multirow[b]{2}{*}{ Cross } & \multicolumn{6}{|c|}{ Gene action parameters } \\
\hline & & & $\mathbf{m}$ & $\mathbf{a}$ & d & $\mathbf{a a}$ & ad & dd \\
\hline \multirow{5}{*}{$\begin{array}{l}\text { No. of spikes } \\
\text { per plant }\end{array}$} & \multirow{3}{*}{$\mathrm{N}$} & $\mathrm{C} 1$ & $13.54 * *$ & 0.22 & $5.15^{*}$ & $3.32 *$ & 0.98 & 2.45 \\
\hline & & $\mathrm{C} 2$ & $8.56 * *$ & $2.96 * *$ & $10.65 * *$ & $7.28 *$ & $6.13 * *$ & $-11.61 * *$ \\
\hline & & C3 & $10.56^{* *}$ & -0.75 & $11.18^{* *}$ & $8.30 * *$ & 1.16 & -0.40 \\
\hline & \multirow[b]{2}{*}{$\mathrm{S}$} & $\overline{\mathrm{C} 1}$ & $8.51 * *$ & -1.11 & 1.11 & -1.46 & 0.69 & $6.82 *$ \\
\hline & & $\mathrm{C} 2$ & $5.81 * *$ & $2.67 * *$ & $9.50 * *$ & $7.34 * *$ & $2.50 *$ & $-9.61 *$ \\
\hline \multirow{5}{*}{$\begin{array}{l}\text { Plant height } \\
(\mathrm{cm})\end{array}$} & \multirow{3}{*}{$\mathrm{N}$} & $\mathrm{C} 1$ & $109.21 * *$ & $5.91 * *$ & $7.67 *$ & $5.14 *$ & $4.51 * *$ & -4.74 \\
\hline & & $\mathrm{C} 2$ & $114.88 * *$ & $-2.04 *$ & $13.71 * *$ & $10.04^{*}$ & $-3.44^{*}$ & -5.34 \\
\hline & & C3 & $107.98 * *$ & 1.71 & $13.42 * *$ & $9.22 *$ & -1.62 & -8.37 \\
\hline & \multirow[b]{2}{*}{$\mathrm{S}$} & $\mathrm{C} 1$ & $98.55 * *$ & $4.62 * *$ & 2.64 & -2.72 & 0.45 & 4.23 \\
\hline & & $\mathrm{C} 2$ & $104.36^{* *}$ & $-1.70 *$ & $14.20 * *$ & $9.16^{*}$ & -4.17 & -0.36 \\
\hline \multirow{3}{*}{$\begin{array}{l}\text { Main spike } \\
\text { length }(\mathrm{cm})\end{array}$} & \multirow{3}{*}{$\mathrm{S}$} & $\mathrm{C} 1$ & $12.70 * *$ & $1.17^{*}$ & $2.96^{*}$ & $3.02 *$ & 0.51 & $-12.29 * *$ \\
\hline & & $\mathrm{C} 2$ & $11.69 * *$ & $-2.83 * *$ & $4.30 * *$ & 1.54 & $-3.86 * *$ & -2.33 \\
\hline & & $\mathrm{C} 3$ & $9.51 * *$ & $0.75 * *$ & $4.54 * *$ & $3.54 * *$ & $0.55^{*}$ & 0.32 \\
\hline \multirow{6}{*}{$\begin{array}{l}\text { No .of } \\
\text { spikelets per } \\
\text { main spike }\end{array}$} & \multirow{3}{*}{$\mathrm{N}$} & $\mathrm{C} 1$ & $23.25 * *$ & $1.14 *$ & $7.20 * *$ & $6.40 * *$ & 0.61 & -3.68 \\
\hline & & $\mathrm{C} 2$ & $22.02 * *$ & $-2.14 * *$ & $13.14 * *$ & $9.84 * *$ & $-4.44 * *$ & $-6.36^{*}$ \\
\hline & & C3 & $22.03 * *$ & $1.17 *$ & $12.15 * *$ & $10.22 * *$ & 0.57 & $-10.30 * *$ \\
\hline & \multirow{3}{*}{$\mathrm{S}$} & $\mathrm{C} 1$ & $23.19 * *$ & $1.29^{*}$ & $4.428 *$ & $2.86^{*}$ & 0.56 & -2.04 \\
\hline & & $\mathrm{C} 2$ & $20.05 * *$ & $-1.65 *$ & $16.53 * *$ & $12.58 * *$ & $-3.17 * *$ & $-9.54 * *$ \\
\hline & & $\mathrm{C} 3$ & $21.21 * *$ & $1.53 * *$ & $11.05^{* *}$ & $8.66^{* *}$ & $1.39 *$ & $-9.11 * *$ \\
\hline \multirow{6}{*}{$\begin{array}{l}\text { No. of } \\
\text { kernels per } \\
\text { main spike }\end{array}$} & \multirow{3}{*}{$\mathrm{N}$} & $\mathrm{C} 1$ & $66.73 * *$ & $9.10 * *$ & $37.43 * *$ & $27.36^{* *}$ & 1.57 & $-19.38 *$ \\
\hline & & $\mathrm{C} 2$ & $73.36 * *$ & $-10.15 * *$ & $81.97 * *$ & $44.50 * *$ & -20.62 & $-23.78 *$ \\
\hline & & C3 & $70.76^{* *}$ & $7.29 * *$ & $35.85^{* *}$ & $23.42 *$ & $5.99 *$ & -10.75 \\
\hline & \multirow{3}{*}{$\mathrm{S}$} & $\mathrm{C} 1$ & $56.61 * *$ & $6.93 * *$ & $44.16^{* *}$ & $33.18 * *$ & 1.28 & $-31.04 * *$ \\
\hline & & $\mathrm{C} 2$ & $61.40 * *$ & $-8.97 * *$ & $85.08 * *$ & $51.38 * *$ & $-15.81 * *$ & $-26.97 *$ \\
\hline & & $\mathrm{C} 3$ & $55.85 * *$ & $5.59 *$ & $52.56 * *$ & $38.50 * *$ & 0.85 & $-39.49 *$ \\
\hline \multirow{6}{*}{$\begin{array}{l}\text { Main spike } \\
\text { yield }(g)\end{array}$} & & $\mathrm{C} 1$ & $3.00 * *$ & $1.12^{*}$ & $4.21 *$ & $3.28 * *$ & $1.07 * *$ & $-2.61 *$ \\
\hline & $\mathrm{N}$ & $\mathrm{C} 2$ & $3.64 * *$ & $-1.25 * *$ & $7.06 * *$ & $4.22 * *$ & $-1.56 * *$ & -2.51 \\
\hline & & C3 & $2.54 * *$ & $0.67 *$ & $4.11 * *$ & $3.86 * *$ & 0.53 & $-2.93 *$ \\
\hline & & $\mathrm{C} 1$ & $2.88 * *$ & $1.14^{*}$ & $3.93 * *$ & $2.84 * *$ & $1.00 * *$ & $-3.06 * *$ \\
\hline & $\mathrm{S}$ & $\mathrm{C} 2$ & $2.77 * *$ & $-0.67 * *$ & $8.30 * *$ & $5.38 *$ & $-1.14 * *$ & $-2.84 *$ \\
\hline & & C3 & $2.09 * *$ & 0.03 & $3.55 * *$ & $3.06^{* *}$ & -0.05 & -0.86 \\
\hline & & $\mathrm{C} 1$ & $34.09 * *$ & $-5.28 * *$ & $22.39 * *$ & $20.92 * *$ & $-8.75 * *$ & $-27.94 * *$ \\
\hline & $\mathrm{N}$ & $\mathrm{C} 2$ & $19.78 * *$ & -0.39 & $16.20 * *$ & $12.10 *$ & -2.61 & -14.49 \\
\hline Grain yield & & $\mathrm{C} 3$ & $17.22 * *$ & -0.83 & $18.87 *$ & $17.30^{*}$ & -0.05 & $-23.55^{*}$ \\
\hline per plant(g) & & $\mathrm{C} 1$ & $22.30 * *$ & -1.32 & $3.74 * *$ & 0.24 & $-4.82^{*}$ & 4.40 \\
\hline & $\mathrm{S}$ & $\mathrm{C} 2$ & $18.18 * *$ & -2.57 & $15.84 *$ & $11.86^{*}$ & $-4.71 *$ & $-20.61 *$ \\
\hline & & $\mathrm{C} 3$ & $12.90 * *$ & -1.33 & $10.62 *$ & 4.74 & -0.31 & -4.01 \\
\hline & & $\mathrm{C} 1$ & $61.43 * *$ & $4.02 * *$ & -0.54 & -4.48 & $-4.98 * *$ & $-23.44 * *$ \\
\hline & $\mathrm{N}$ & $\mathrm{C} 2$ & $45.16^{* *}$ & -1.06 & $27.65 * *$ & $22.56^{* *}$ & -1.94 & $-26.66^{* *}$ \\
\hline 1000. Kernel & & $\mathrm{C} 3$ & $49.25 * *$ & 0.26 & $17.90^{* *}$ & $14.60 * *$ & 1.09 & -11.40 \\
\hline weight (g) & & $\mathrm{C} 1$ & $41.78 * *$ & $7.77 * *$ & $11.27 * *$ & $9.48 * *$ & 1.45 & $-13.42 *$ \\
\hline & $\mathrm{S}$ & $\mathrm{C} 2$ & $33.28 * *$ & $-1.95 * *$ & $29.05 * *$ & $23.62 * *$ & $-3.13 * *$ & $-23.14 *$ \\
\hline & & $\mathrm{C} 3$ & $26.16^{* *}$ & $-0.74 * *$ & $28.07 * *$ & $20.08 * *$ & 1.19 & -3.95 \\
\hline
\end{tabular}

*** Significant at 0.05 and 0.01 probability levels, respectively.

The dominance gene effects (d)were found to be highly significant for most studied characters(Table 5) except no. of spikes per plant and plant height in first cross under stress condition, for main spike length and 1000- kernel weight in cross I under normal condition. The magnitude of additive gene effects (a) were small relative to the corresponding dominance effects $(d)$ in most cases, suggesting pedigree selection method is useful breeding program for improving these populations. These results are in harmony with those obtained by Khaled (2013), Asadi et al. (2015) and EL-Nahas (2016). On the other hand, significant additive (a) anddominance (d) components indicated that bothadditive and dominance gene effects were importantin the inheritance of these characters. 
Also, selection for desirable characters may be practiced in early generations but it would be effective in the late ones. Similar results were obtained by Khaled (2013).

Significant epistatic additive $\mathrm{x}$ additive (Table 5) type of gene effects (aa) was detected in most studied characters except no. of spikes per plant, plant height in the first cross under stress treatment, main spike length in first and second cross under normal and second cross only under stress, grain yield per plant in the first and third cross under stress condition and 1000-kernel weight in the first cross under normal.

Additive $\mathrm{x}$ dominance epistatic type of gene effects (ad) was found to be significant (Table 5) for no. of spikes per plant, in the second cross under both conditions, plant height in first cross was positive and significant and second cross was negative and positive under normal case, main spike length in second cross was negative and positive under both cases and it was positive and significant in third cross under both cases, no. of spikelets per main spike in the second cross under both case and third cross only under stress, no. of kernels per spike in the third cross under normal and second cross under stress, main spike yield in the first and second cross under both conditions, grain yield per plant in first cross under both condition and second cross under stress and 1000-kernel weight in first cross under normal and second cross under stress. The negative sign of additive $\mathrm{x}$ dominance (ad) interaction in most cases also suggested dispersion of genes in the parents.

The third type of epistatic effect dominance $\mathrm{x}$ dominance (dd) (Table 5) effects were significantly detected for most characters except no. of spike per plant in the third cross under both condition and first cross only under normal, plant height in all crosses under both condition, main spike length in first and second cross under normal, second and third cross under stress, no. of spikelets per main spike in first cross under both condition, no. of kernels per main spike in third cross under normal, main spike yield in second cross under normal and third cross under stress, grain yield per plant in second cross under normal, first and third under stress and 1000-kernel weight in third cross under both conditions. These results are in agreement with those obtained by Khaled (2007), Farag (2009), Khattab et al . (2010).

The study further revealed the epistatic gene effectswere important as additive and dominance geneeffects for most of the studied charactersand hence detection, estimation and consideration of epistasis is important for the formulation of breeding programs to improve a given wheat population for such characters. Such conclusions have also been drawn by Elmassry et al. (2016).

Insignificant positive or negative results in the three crosses under the two environments reveal that the materials used in this study have more alleles controlling the studied characters and selection may be effective to improve these characters.

In general, the inheritance of all studied characters was found to be controlled by additive and non-additive gene action i.e. dominance and epistasis, consequently selection procedures based on the accumulation of additive effect would be successful in improving all characters under investigation. However, to maximize selection advance, procedures which are known to be effective in shifting gene frequency when both additive and non-additive genetic variances are involved would be preferred. Similar results were previously reported by Dawwam et al. (2007), Ghanem (2008) and Elmassry (2009).

Heritability estimatesand genetic advance:

Knowledge of heritability of a trait guides a plant breeder to predict behavior of succeeding generations and helps to predict the response to selection. Estimation of broad-sense heritability estimates (Table 6) indicated higher importance of genetic effects in control of characters. Comparison between broad and narrow-sense heritability estimates revealed equal importance of additive and non-additive effects in genetic control of characters.

Plant breeders, through experience, can perhaps rate aseries of their response to selection. Heritability gave a numerical description of this concept. Assessment of heritability of various characters is of considerable important in crop improvement program, for example, to predict response to selection, Nyguist (1991).

High heritability estimates in broad sense were detected for all studied characters in the three crosses under both conditions except main spike yield (44.52) in the first cross under stress case. Narrow sense heritability estimates were found to be high for main spike length, no .of spikelets per main spike and no. of kernels per main spike in all crosses under both conditions, no. of spikes per plant in first cross under both cases and second cross under normal case, plant height in the three crosses under both conditions except second cross under stress, main spike yield in second cross under stress, grain yield per plant in the first and second cross under normal and second cross under stress and 1000Kernel weight in second cross under normal. These results indicate that selection may be more effective for improving these characters of genotypes in early generations

Low estimates of narrow sense heritability were found for 1000-kernel weight (29.44) in the second cross under stress. While other characters found to be moderate estimate. These results indicate that environmental effects have a larger contribution than genetic effects for these characters. 
Table 6: Heritability estimates and genetic advance expressed as a percent of the F2 mean ( $\Delta \mathrm{g} \%)$ in the three bread wheat crosses (I) Gemmeiza 11× Giza 168, (II) Giza 171× Shandawel 1 and (III) Gemmeiza 9× Misr 1 under normal (N) and stress $(\mathrm{S})$ conditions.

\begin{tabular}{|c|c|c|c|c|c|}
\hline \multirow{2}{*}{ Characters } & \multirow{2}{*}{ Condition } & \multirow{2}{*}{ Cross } & \multicolumn{2}{|c|}{ Heritability } & \multirow{2}{*}{$\Delta \mathbf{g} \%$} \\
\hline & & & Broad sense & Narrow sense & \\
\hline \multirow{6}{*}{ No. of spikes per plant } & \multirow{3}{*}{$\mathrm{N}$} & $\mathrm{C} 1$ & 77.67 & 66.90 & 40.11 \\
\hline & & $\mathrm{C} 2$ & 66.46 & 64.82 & 72.98 \\
\hline & & $\mathrm{C} 3$ & 76.52 & 37.08 & 32.85 \\
\hline & \multirow{3}{*}{$\mathrm{S}$} & $\mathrm{C} 1$ & 73.21 & 68.57 & 82.65 \\
\hline & & $\mathrm{C} 2$ & 67.28 & 42.06 & 57.76 \\
\hline & & $\mathrm{C} 3$ & 80.72 & 42.08 & 83.45 \\
\hline \multirow{6}{*}{ Plant height $(\mathrm{cm})$} & \multirow{3}{*}{$\mathrm{N}$} & $\mathrm{C} 1$ & 89.34 & 79.34 & 7.99 \\
\hline & & $\mathrm{C} 2$ & 66.08 & 61.96 & 7.85 \\
\hline & & $\mathrm{C} 3$ & 71.33 & 54.64 & 7.75 \\
\hline & \multirow{3}{*}{$\mathrm{S}$} & $\mathrm{C} 1$ & 89.34 & 79.34 & 8.29 \\
\hline & & $\mathrm{C} 2$ & 66.08 & 61.96 & 6.88 \\
\hline & & $\mathrm{C} 3$ & 71.33 & 54.64 & 12.16 \\
\hline \multirow{6}{*}{ Main spike length $(\mathrm{cm})$} & \multirow{3}{*}{$\mathrm{N}$} & $\mathrm{C} 1$ & 87.79 & 47.80 & 25.83 \\
\hline & & $\mathrm{C} 2$ & 92.74 & 80.11 & 54.16 \\
\hline & & $\mathrm{C} 3$ & 84.96 & 83.95 & 44.10 \\
\hline & \multirow{3}{*}{ S } & $\mathrm{C} 1$ & 79.11 & 62.66 & 35.09 \\
\hline & & $\mathrm{C} 2$ & 76.11 & 68.77 & 35.76 \\
\hline & & $\mathrm{C} 3$ & 71.92 & 66.21 & 21.37 \\
\hline \multirow{6}{*}{ No .of spikelets per main spike } & \multirow{3}{*}{$\mathrm{N}$} & $\mathrm{C} 1$ & 93.32 & 62.67 & 34.79 \\
\hline & & $\mathrm{C} 2$ & 91.86 & 87.17 & 35.57 \\
\hline & & $\mathrm{C} 3$ & 79.40 & 70.44 & 19.27 \\
\hline & \multirow{3}{*}{$\mathrm{S}$} & $\mathrm{C} 1$ & 84.76 & 76.24 & 23.56 \\
\hline & & $\mathrm{C} 2$ & 88.36 & 76.40 & 32.44 \\
\hline & & $\mathrm{C} 3$ & 83.78 & 75.78 & 23.12 \\
\hline \multirow{6}{*}{ No. of kernels per main spike } & \multirow{3}{*}{$\mathrm{N}$} & $\mathrm{C} 1$ & 85.55 & 62.67 & 22.13 \\
\hline & & $\mathrm{C} 2$ & 65.72 & 60.86 & 19.38 \\
\hline & & $\mathrm{C} 3$ & 69.52 & 64.89 & 26.88 \\
\hline & \multirow{3}{*}{$\mathrm{S}$} & $\mathrm{C} 1$ & 83.70 & 62.95 & 22.31 \\
\hline & & $\mathrm{C} 2$ & 68.87 & 60.44 & 25.35 \\
\hline & & $\mathrm{C} 3$ & 70.96 & 66.63 & 38.99 \\
\hline \multirow{6}{*}{ Main spike yield(g) } & & $\mathrm{C} 1$ & 53.72 & 45.95 & 39.05 \\
\hline & $\mathrm{N}$ & $\mathrm{C} 2$ & 76.05 & 40.47 & 41.98 \\
\hline & & $\mathrm{C} 3$ & 76.49 & 37.98 & 60.60 \\
\hline & & $\mathrm{C} 1$ & 44.52 & 40.38 & 34.85 \\
\hline & $\mathrm{S}$ & $\mathrm{C} 2$ & 75.33 & 60.07 & 76.36 \\
\hline & & $\mathrm{C} 3$ & 63.82 & 41.37 & 62.12 \\
\hline & & $\mathrm{C} 1$ & 61.52 & 56.50 & 38.98 \\
\hline & $\mathrm{N}$ & $\mathrm{C} 2$ & 60.02 & 58.66 & 74.39 \\
\hline Grain vield per plant(g) & & $\mathrm{C} 3$ & 82.92 & 43.77 & 84.98 \\
\hline Grain yield per plant(g) & & $\mathrm{C} 1$ & 68.70 & 44.23 & 44.45 \\
\hline & $\mathrm{S}$ & $\mathrm{C} 2$ & 79.03 & 47.32 & 75.82 \\
\hline & & $\mathrm{C} 3$ & 86.14 & 36.87 & 73.62 \\
\hline & & $\mathrm{C} 1$ & 71.12 & 44.11 & 11.01 \\
\hline & $\mathrm{N}$ & $\mathrm{C} 2$ & 76.83 & 59.05 & 25.03 \\
\hline & & $\mathrm{C} 3$ & 81.70 & 34.34 & 17.73 \\
\hline 1000. Kernel weight (g) & & $\mathrm{C} 1$ & 70.55 & 33.07 & 10.22 \\
\hline & $\mathrm{S}$ & $\mathrm{C} 2$ & 81.84 & 29.44 & 22.46 \\
\hline & & $\mathrm{C} 3$ & 59.67 & 37.74 & 23.08 \\
\hline
\end{tabular}


Similar approaches of broad-sense heritability estimates were coincident with those reported by Hammad et al. (2012) for plant height, number of spikes per plant, number of kernels per spike, kernel weight and grain yield per plant. Khaled (2013) for kernel weight and grain yield. Sharaan et al, (2017),reported higher heritability than $80 \%$ for plant height, spike length, no. of spikelets for the main spike, grains weight, 1000-grain weight, grain yield plant, no. of spikes. On theother hand, the results of heritability in narrowsense were similar to these obtained by Abd-El-Haleem et al. (2009), for low estimate of spikes/plant and were moderately high for grain yield/plant. Also, Abd El-Rahman (2013)detected moderate estimate for plant height and grain yield per plant.

These results suggest that dominance gene action was primarily responsible for the inheritance of most characters in these crosses. Heritability in narrow sense as estimated using F2 and backcross data were high for most characters in these crosses. These results indicate thatselection may be more effective for improving characters of genotypes in early generations. On contrary, low narrow sense heritability was detected for1000-kernel weight in the second cross under stress. These results indicate that environmental effects have a larger contribution than genetic effects for these characters.

The genetic advance as percentage of the F2 mean for the studied characters is presented in Table (6). Genetic advance gives clear picture and precise view of segregating generations for possible selection. Higher estimates of heritability coupled with better genetic advance confirm thescope of selection in developing new genotypes with desirable characteristics.

High values of genetic advance are indicative of additive gene action whereas low values are indicative of non-additive gene action (Singh and Narayanan 1993). Thus the heritability estimates will be reliable if accompanied by high genetic advance. Moderate to high genetic advance $(\Delta \mathrm{g} \%)$ was detected for all characters in the three crosses under the two environments except, plant height for the three crosses under normal condition and first and second cross under stress condition.

The highest estimates of narrow sense heritability associated with highest genetic advance for most of the studied characters in most of crosses under both condition indicated sufficient improvement of their variability characters. These results indicated the possibility of practicing selection in early generations for these characters. As for the remaining characters, selection for these characters would be effective, but probably of less success than in the former characters. These results are in general agreement with those obtained by
Khattab et al. (2010), Abd El-Rahman, (2013), Khaled, (2013) and Naheif (2014).

However, since the present experiment was conducted at two different environmental conditions (normal and water stress) for a season, the estimates of additive and dominance components are confounded with environmental effects (location, season... etc.). The characters which showed absence of epistasis may give evidence of epistasis under other environmental conditions. Similarly, the characters which showed presence of significant epistasis may not do so if it is tested in other environments. Therefore, more elaborate experiments have to be conducted to get a clear picture about the genetic systems controlling these characters in order to develop more efficient breeding procedures.(Subbaraman and Rangasamy, (1989) and Sadat and Sokhansanj, (2004).

\section{REFERENCES}

Abd El-Rahman, Magda E. (2013). Estimation of Some Genetic Parameters through Generation Mean Analysis in Three Bread Wheat Crosses. Alex. J. Agric. Res.Vol. 58, No.3, pp.183-195.

Abd-El-Haleem, S.H.M., M.A. Reham and S.M.S. Mohamed (2009). Genetic analysis and rapd polymorphism in some durum wheat genotypes.Global J. Biotech.\&Biochem., 4 (1): 01-09,

Akhtar, N. and M.A. Chowdhry (2006). Genetic analysis of yield and some other quantitative characters in bread wheat. Int. J. Agric. Biol., 8: 523-527.

Asadi, A. A., M. Valizadeh, S. A. Mohammadi and A. Khodarahmi (2015). Genetic analysis of some physiological characters in wheat by generations mean analysis under normal and water deficit conditions. Biological Forum- An Int. J. 7(2):722-733.

Dawwam, H. A.; F. A. Hendawy and Marwa M. E1Nahas (2007).Geneticalbehavriour of some quantitative characters in bread wheat (Triticum aestivum L.).Minufiya J. Agric. Res., 32 (4): $1037-1054$.

Ehdaie, B. and G.G., Waines (1993). Variation in water-use efficiency and its components in wheat. I. Well-watered pot experiment. Crop Sci. 33, 294-299.

El-Hawary, M.N.A. (2006). Breeding for drought tolerance in bread wheat.M.Sc. Thesis, Fac. of Agric, Mansoura Univ., Egypt. 
Elmassry, E. L., A. A. Morad, Marwa, M. El-Nahas, H. A. Dawwam, F. A.Hendawy and M. A. Abo Shereif (2016). Evaluation of bread wheat tripletest cross (TTC) families under normal and water stress conditions. The SixField Crops Conference 22-24 Nov. Giza, Egypt.

Elmassry, E.L. (2009). Detecting of epistasis in bread wheat (Triticumaestivum L.). M.Sc. Thesis, Faculty of Agric.,Minufiya Univ., Egypt.

El-Nahas, Marwa M. (2016). Estimation of gene action for yield and its components characters in bread wheat under drought condition. Alex. J. Agric. Res. 61(3):307-314

Farag,H.I.A. (2009).Inheritance of yield and its components in bread wheat (Triticum aestivum L.) using six parameter model under RasSudr conditions.6th International Plant Breeding Conference, Ismailia, Egypt, 90-112.

Farshadfar, E., M.Ghandha,M. Zahravi, and J. Sutka, (2001). Generation mean analysis of drought tolerance in wheat (Triticum aestivum L.).ActaAgron. Hung. 49, 59-66.

Farshadfar, E., M.Aghaie, M. Sharifi, and A. Yaghotipoor, (2008). Assessment of salt tolerance inheritance in barley via generation mean analysis. J. Biol. Sci. 8, 461-465.

Fonseca, S. and F.L. Patterson, (1968). Hybrid vigour in seven parental diallel crosses in common wheat (Triticum aestivum L.). Crop Sci., 8: $85-88$

Gamble, E.E. (1962). Gene effects in corn (Zea mays L.). 1. Separation and relative importance of gene effects for yield. Can. J. Plant Sci. 42: 339-348.

Ghanem , W.M. (2008). Genetic analysis of grain yield and other quantitative characters in some crosses of bread wheat (Triticum aestivum L.) Ph.D. Thesis, Faculty of Agric., Minufiya Univ., Egypt.

Hammad, S.M., E.H. El-Seidy and M. A. H. Darwesh (2012). Inheritance of yield and its components in some spring wheat crosses. Proc. $13^{\text {th }} \quad$ International Conf. Agron.,Fac.ofAgic., Benha Univ., Egypt, 9-10 September 2012. 206 - 221.

Johnson, H. W., H. F. Robinson and R. E. Comstock (1955). Estimates of genetic and environmental variability in soybean.Agron. J., 47: 314-338.

Khaled, M.A.I. (2007). Estimation of genetic variance for yield and yield components in two bread wheat (Triticum aestivum L.) crosses. J. Agric. Sci. Mansoura Univ., 32(10): 80438053.
Khaled, M. A. I. (2013). Genetic system controlling the yield and its components in three bread wheat (Triticum aestivum,L.) Crosses. Egypt. J. Agric. Res., 91(2), 641-653.

Khattab, S.A.M., R.M. Esmail and A.M.F. ALAnsary (2010). Genetical analysis of some quantitative characters in bread wheat (Triticum aestivum L.). New York Science Journal, 3(11): 152-157.

Mather, K. (1949). Biometrical Genetics.Dover puplications, Inc., London.

Mather, K. and J. L. Jinks (1982). Biometrical Genetics.( $3^{\text {rd }}$ edition), Chapman and Hall, London.

Memon, J., (2010). Genetic basis of heat tolerance in bread wheat (Triticum aestivum L.).Ph.D. Thesis, University of Agriculture, Faisalabad.

Miller, P. A., J. C. Williams, H. F. Robinson and R. E. Comstock (1958). Estimates of genotypic and environmental variances and covariances in upland cotton and their implications in selection.Agron. J., 50: 126-131.

Munesh, K. K., V.S.Kandalkar and N. Satankar (2018). Genetic analysis through different generation means for grain yield and attributing characters in bread wheat (Triticum aestivum L.) J. of Pharmacognosy and Phytochemistry. SP2: 195-198.

Naheif E. M. M.(2014). Genetic control for some characters using generation mean analysis in bread wheat (Triticum aestivum L.). International J. of Plant \& Soil Science 3(9): 1055-1068.

Nyguist, W.E. (1991). Estimation of heritability and prediction of response in plant populations. CRC Critical Reviews in Plant Science, 10(3): 235-322.

Sadat, N. S.A. and A.Sokhansanj (2004).nTriple test cross analysis for genetic components of salinity tolerance in spring wheat. J. of Sci., Islamic Rep. of Iran, 15(1): 13-19.

Sharaan, A. A. N., K. H. Ghallab and M.A.S. M. Eid (2017). Estimation of genetic parameters for yield and its components in bread wheat (Triticum aestivum,L.) genotypes under pedigree selection. Int. J. Agron. Agri. R. Vol. 10, No. 2, p. 22-30.

Singh P. and S.S. Narayanan(1993). Biometrical Techniques in Plant Breeding. $1^{\text {st }}$ EdnKalayani publishers, New Delhi, India

Subbaraman N. and S.R.S. Rangasamy(1989). Triple test cross analysis in rice. Euphytica, 42: 35-40 (1989).

Zaazaa, E.I., M.A. Hager and E.F. El-Hashash (2012). Genetical analysis of some quantitative characters in wheat using six parameters genetic model. American- Eurasian J. Agric. \& Environ. Sci., 12 (4):456-462. 


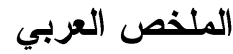

\author{
السلوك الوراثى لبعض الصفات المحصولية فى ثلأثة هجن من قمح الخبز تحت ظروف بيئية مختفة \\ 'لسبا لطقى المصرى'، مروه محمد النحلس'

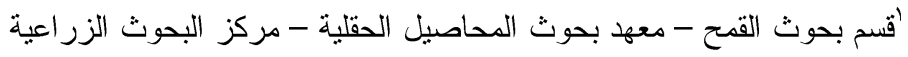 \\ كآقسم المحاصبل - كلية الزر اعة - جامعة المنوفية
}

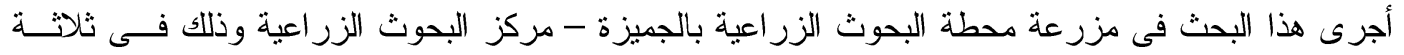

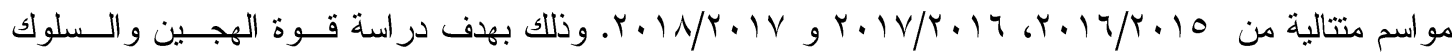

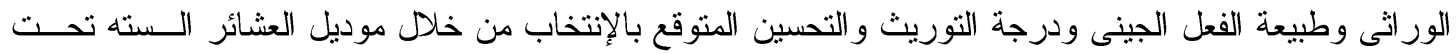

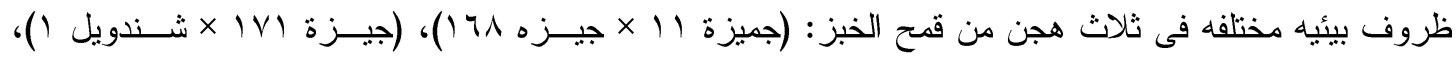

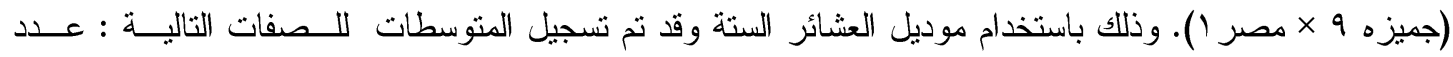

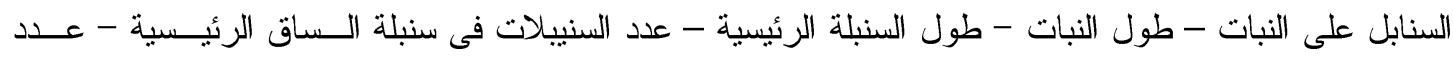
الحبوب فى سنبلة الساق الرئيسية - محصول سنبلة الساق الرئيسية - محصول النبات الفردى - وزن الألف حبنة النية. ويمكن تلخيص أهم النتائج للثلاث هجن المدروسة تحت الظروف البيئيه المختلفه فيما يلى: (Y) وجدت اختلافات ور اثية معنوية فى عشائر الجيل الثاني لجميع الصفات المدروسة.

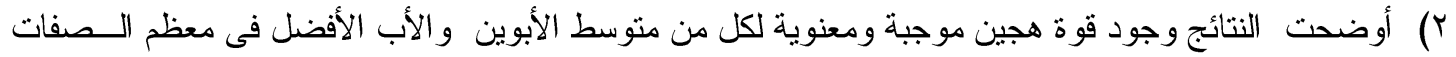
المدروسة للثلاث هجن تحت الدر اسة.

r) كان تأثثر التربية الداخلية معنويا وموجبا فى معظم الصفات المدروسة للثنلاث هجن تحت الدر اسة. وذات تأثثر

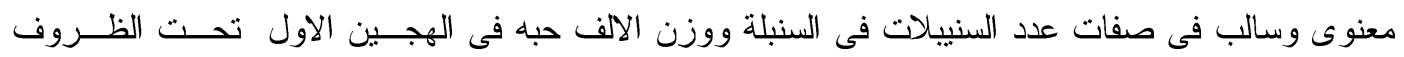
الطبيعية.

ع) كان الفعل الجينى المضيف معنوي لمعظم الصفات المدروسة تحت الظروف العادية وظروف الاجهاد. 0) كان الفعل الجينى السيادى عالى المعنوية لمعظم الصفات تحت الدراسة فيما عدا صفة عدد السنابل على النبـات التهات وطول النبات فى الهجين الاول تحت ظروف الاجهاد وطول السنبلة الرئيسية ووزن الالف حبة فـى الهجـين الاول تحت الظروف العادية. ؟) كانت قيمة درجة التوريث بمعناها العام عالية لكل الصفات المدروسة تحت الظروف العادية وظروف الاجهـاد فيما عدا صفة محصول السنبلة الرئيسية تحت ظروف الاجهاد. وكذلك قيمة درجة التوريث بمعناها الدقيق كانت

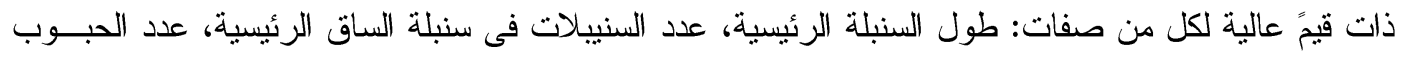
فى سنبلة الساق الرئيسية تحت الظروف العادية وظروف الاجهاد فى الثلاث هجن تحت الدراسة

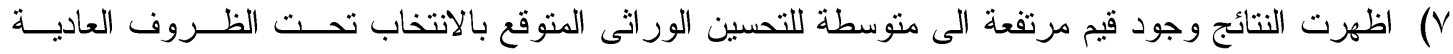

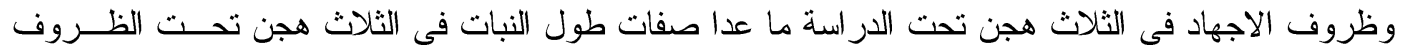

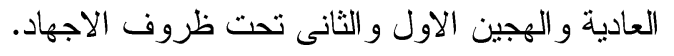

^) أظهرت النتائج أن القيم العالية للنسبة المئوية للتحسين الور اثلى المتوقع بالانتخاب مصاحبة للقيم العالية لدرجة

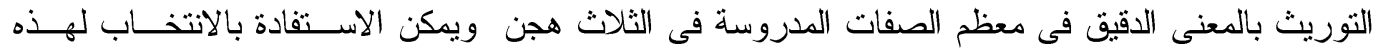

$$
\text { الصفات فى الاجيال المبكرة. }
$$

